
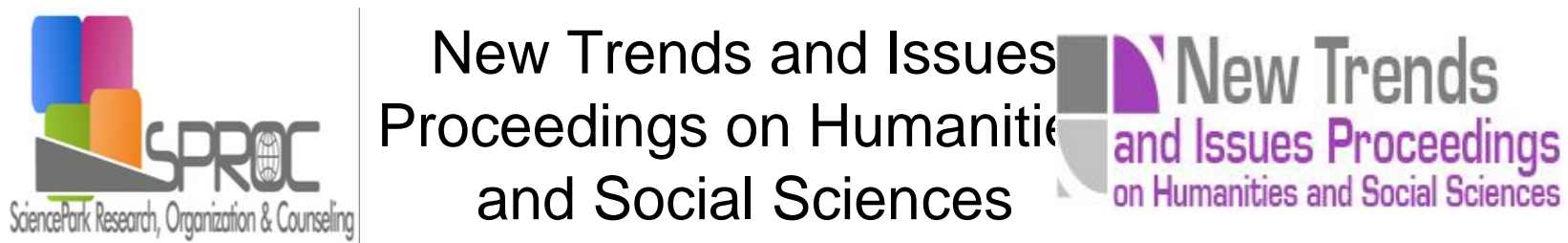

\title{
Teaching mathematics with children's literature in Finland
}

\author{
Juli-Anna Aerila ${ }^{*}$ * \\ Miikka Wikholm
}

Suggested Citation:

Issues Proceedings on Humanities and Social Sciences.

Abstract

the extent to which they use children's literature in teaching mathematics in primary school how to efficiently use children's literature in teaching mathematics in primary school 
1. Introduction

\subsection{Fiction in primary school mathematics lessons}

1.1.1.The natural connection of mathematics and literature 
Tehtava maassa Mission in

Earth

1.1.2. Pedagogical approaches to enhance the use literature in mathematics teaching 
2.Research design and analysis 

the feeling that only small children will benefit from the integration

knowledge lack of materials the fe
of mathematics and children's literature

lack of time

$$
p=0,014)
$$

lack of time

Table 1. The main reasons preventing the use of children's literature in teaching mathematics $(n=44)$.

$p-$

\begin{tabular}{l} 
Lack of need \\
Lack of time \\
Extended \\
dependency on \\
subject's school \\
books \\
Impossibility of \\
integration \\
Lack of \\
knowledge \\
Lack of materials \\
$\quad$ Feeling that only \\
small children will \\
benefit from the \\
integration of \\
mathematics and \\
children's literature \\
\hline
\end{tabular}

3.3. The main approaches to using children's literature in mathematics lessons in Finland 


\section{Discussion}

\section{References}

Research in Mathematics Education, 35

Mathematics Teaching in the Middle School, 10

Reading Psychology 27 
handbook of qualitative research $4^{\text {th }}$ edition

The 62nd Annual Conference of the Literacy Research Association

Mathematics Education Research Journal, 22

Perusopetuksen perusteluonnokset (2016)

research on teaching

Frontiers in Psychology, 5

Handbook of

Edition,

Matematiikka - Nakökulmia opettamiseen ja oppimiseen 2nd

development and education in Japan

Child

Reading Teacher, 54

Teaching Children Mathematics 4

Early Childhood Research Quarterly, 11

The

Reading Teacher, 57

Beyond communication. Reading comprehension and criticism

Causal inference for statistics, social, and biomedical sciences: An

introduction.

Tehtava maassa

Matematiikka - Nakökulmia opettamiseen ja oppimiseen 2nd Edition

Australasia

Proceedings of the Annual Conference of the Mathematics Education Research Group of

Journal of Research in Childhood Education, 24 The Reading Teacher, 67

Poetic justice. The literary imagination and public life

Drama: Threat or opportunity? Managing the 'dual affect' in process drama 
The SAGE handbook of qualitative research $4^{\text {th }}$ edition

kaytantö

Uusien maailmojen viestit: Kirjallisuuden lukemisen semioottis-psykolingvistinen teoria ja

IUMPST: The Journal, 2

Early

childhood research quarterly, 19 